\title{
PERENCANAAN BAHASA DI INDONESIA BERBASIS TRIGLOSIA ${ }^{i}$
}

\author{
Gufran Ali Ibrahim ${ }^{1)}$, Luh Anik Mayani2) * \\ Badan Pengembangan dan Pembinaan Bahasa, Kementerian Pendidikan dan Kebudayaan ${ }^{1{ }^{12)}}$ \\ Universitas Khairun ${ }^{1)}$ \\ ibrahim.kakalu@gmail.com ${ }^{1)}$,annie_mayani@yahoo.com ${ }^{2)}$
}

\begin{abstract}
For regions or countries with language plurality, which gives impact to cultural plurality, language planning becomes a complex matter. This study proposes concepts on language planning which can be applied in multilingual countries like Indonesia. Based on literary research on language situations in some countries, this study describes the language situation in those countries and compares it the language situation in Indonesia. The conclusion is that the implementation of language planning in Indonesia needs various strategies; there is no single strategy which can be well applied for the whole linguistic situation in the country. Language planning in Indonesia should be started by corpus planning as a strategy to preserve local vernaculars from language endangerment. The next step is determining regulation in order to divide the domains of language use: (1) the use of Indonesian language and local vernacular(s)/colloquial(s) in diglossic regions and (2) the use of Indonesian language, the "intermediate" language and local vernaculars(s) in triglossic regions.
\end{abstract}

Keywords: language planning, diglossia-triglossia, strategy to preserve local vernacular(s)

\begin{abstract}
Abstrak
Bagi wilayah atau negara yang majemuk bahasa, yang juga berimplikasi pada majemuk budaya, perencanaan bahasa menjadi urusan yang rumit. Tulisan ini menyajikan konsep perencanaan bahasa yang dapat diterapkan di negara multilingual seperti Indonesia. Berdasarkan kajian pustaka tentang situasi kebahasaan di beberapa negara, tulisan ini mendeskripsikan kondisi kebahasaan di negara-negara tersebut dan membandingkannya dengan kondisi yang ada di Indonesia. Simpulannya adalah bahwa implementasi perencanaan bahasa di Indonesia memerlukan strategi yang beragam; satu strategi tidak dapat diterapkan untuk semua kondisi. Perencanaan bahasa di Indonesia harus dimulai dengan perencanaan korpus sebagai strategi penyelamatan bahasa-bahasa etnik dari ancaman kepunahan. Langkah lanjutannya adalah penetapan regulasi untuk memastikan proporsi ranah pemakaian bahasa: (1) pemakaian bahasa Indonesia dan bahasa etnik/kolokuial untuk wilayah diglosik dan (2) pemakaian bahasa Indonesia, bahasa ragam tengahan, dan bahasa etnik untuk wilayah triglosik.
\end{abstract}

Kata kunci: perencanaan bahasa, diglosia-trigosia, strategi penyelamatan bahasa etnik

\section{PENGANTAR}

Dalam literatur perencanaan bahasa (language planning) dikenal ada dua jenis perencanaan bahasa: (1) usaha-usaha memodifikasi bahasa dan (2) usaha-usaha memodifikasi lingkungan tempat bahasa digunakan (Sallabank, 2011:278). Dalam usaha memodifikasi bahasa diperlukan empat tahap: (1) penemuan fakta awal mengenai situasi kebahasaan, (2) pemastian atau penentuan bahasa yang dipilih untuk dimodifikasi, (3) implementasi perencanaan, dan (4) 
evaluasi atas hasil-hasil pelaksanaan modifikasi bahasa. Agar implementasi perencanaan bahasa berhasil, ada lima faktor penentu yang perlu diperhatikan atau dipertimbangkan: (1) demografi kemasyarakatan, (2) bahasa, (3) psikologi masyarakat, (4) politik, dan (5) agama (Appel \& Mysken, 1981 dalam Mukhuba, 2004).

Berbeda dengan kebijakan bahasa (language policy), perencanaan bahasa perlu dilakukan berdasarkan penelusuran dan pengukuran terhadap fakta-fakta atau situasi kebahasaan di lapangan (Sallabank menyebutnya sebagai bottom-up) dan karena itu perencanaan bahasa haruslah merupakan praktik dan pengukuran yang konkret atas tindakan terhadap bahasa yang akan dimodifikasi, baik dari segi penetapan statusnya (status planning) maupun dari pembakuan kosakata dan gramatika (corpus planning).

\section{TIGA LANGKAH UNTUK TIGA ISU KEBAHASAAN}

Bagi negara atau kawasan monolingual, perencanaan bahasa yang bertujuan untuk menetapkan bahasa yang dipromosikan sebagai bahasa resmi atau bahasa nasional dan untuk membakukan gramatika bahasa tidaklah terlalu sulit dilakukan. Pemilihan bahasa yang dipromosikan, dibakukan, atau dinaikkan fungsinya tidak lagi menjadi urusan yang rumit karena hanya ada satu bahasa di kawasan atau negara tersebut.

Tidak demikian halnya dengan negara atau kawasan multilingual dan juga multibudaya. Bahasa yang dipilih untuk ditetapkan sebagai "bahasa utama" bukanlah perkara gampang. Selain harus dimulai dari penemuan fakta dan pemetaan situasi kebahasaan dari berbagai kawasan, perencanaan bahasa harus pula mempertimbangkan faktor sosial, demografi, politik, bahkan juga agama. Belum lagi, bila kawasan atau negara multilingual tersebut memiliki ciri sebagai negara yang diglosik ${ }^{\text {ii }}$ dan juga triglosik. ${ }^{\text {iii }}$ Bagi wilayah atau negara majemuk bahasa, yang juga selalu berimplikasi pada majemuk budaya, perencanaan bahasa menjadi urusan yang rumit. Kerumitan ini karena beberapa hal. Pertama, perencanaan memerlukan studi atau pemetaan sosio-etnolinguistik yang akurat. Kedua, pemastian bahasa apa yang dipromosikan atau dibakukan memerlukan diskusi dengan berbagai pihak yang berkepentingan dan dalam diskusi tersebut kemungkinan perdebatan bisa saja dinamis. Ketiga, implementasi atas perencanaan pun memerlukan strategi yang beragam untuk kondisi yang beragam pula. Satu strategi tidak bisa diterapkan untuk semua implementasi.

Setakat ini perencanaan bahasa yang berhubungan dengan penetapan satu bahasa sebagai bahasa negara telah dilakukan (di) Indonesia dan relatif telah mapan: bahasa Indonesia telah menjadi bahasa nasional, bahasa negara, bahasa pemerintahan, dan bahasa pendidikan. Pembakuan, sebagai salah satu wujud perencanaan korpus pun telah lama dilakukan dan sudah relatif stabil pula. Pusat Bahasa yang kini menjadi Badan Pengembangan dan Pembinaan Bahasa sebagai lembaga yang diberi tugas untuk ini telah melakukan dua hal ini dengan sukses.

Perencanaan ulang bahasa-(bahasa) di Indonesia bertujuan untuk memastikan semua bahasa etnik bertumbuh-kembang secara adil: bahasa Melayu Tempatan (selanjutnya disingkat MT) ${ }^{\text {iv }}$ dan Kolokuial Jakarta (selanjutnya disingkat KJ) ${ }^{v}$ menjadi "bahasa tengahan" yang proporsional dan memastikan bahasa Indonesia tetap menjadi perekat keindonesiaan. Selanjutnya, ada tiga fakta kebahasaan terkini yang mendorong perlunya perencanaan ulang bahasa(-bahasa) tersebut, yaitu (1) ancaman kepunahan bahasa-bahasa etnik di sebagian wilayah, terutama di timur Indonesia, (2) semakin luasnya penggunaan KJ hingga menggerus ranah penggunaan bahasa Indonesia, serta (3) semakin bertambahnya populasi warga urban dan 
terbentuknya kelompok kelas menengah Indonesia pengguna MT yang ternyata tidak hanya meninggalkan teritorial tradisionalnya, tetapi juga sekaligus "meninggalkan" bahasa etniknya lalu menjadikan MT sebagai mother tongue baru bagi generasi berikutnya.

Tiga situasi kebahasaan seperti ini menentukan sifat relasi antarbahasa di Indonesia. Sifat relasi ini dapat diringkaskan: bahasa etnik semakin jarang dipakai, MT semakin sering digunakan, dan semakin cepat menjadi bahasa pertama bagi warga kota. Situasi ini terutama terjadi di kawasan timur Indonesia. Situasi kebahasaan di Jakarta menunjukkan semakin masuknya KJ ke ranah pakai yang sejatinya merupakan ranah pakai bahasa Indonesia. MT yang menekan bahasa etnik akan mempercepat kepunahan bahasa etnik, sedangkan KJ yang menggerus bahasa Indonesia dalam jangka panjang bisa jadi menggantikan posisi bahasa Indonesia sebagai bahasa nasional.

Bila kita ingin memastikan bahasa-bahasa etnik di Indonesia sebagai bagian pentingstrategis bagi keindonesiaan; bila kita ingin tetap menjadikan bahasa Indonesia sebagai bahasa nasional dan merupakan "tempat berjumpa"-nya orang Indonesia; dan bila kita masih tetap menjadikan KJ dan MT menjadi lingua franca bagi beragam komunitas dan etnik di Indonesia, perencanaan bahasa di Indonesia kini tidak hanya perlu dirumuskan kembali, tetapi juga diperlukan cara baru dalam perencanaan bahasa.

Disebut cara baru karena perencanaan bahasa kini tidak sekadar urusan pembakuan dan pemartabatan bahasa Indonesia serta pendataan bahasa-bahasa daerah seperti yang dilakukan selama ini. Cara baru dalam penanganan perencanaan bahasa sangat diperlukan mengingat sifat relasi antara bahasa etnik dan MT serta sifat relasi antara bahasa Indonesia dan KJ dalam konteks tampilnya kelas menengah baru di kota-kota besar di Indonesia sebagai penghela kemajuan sosial-politik-ekonomi. Cara baru perencanaan tersebut perlu diawali dengan (1) pemetaan vitalitas bahasa-bahasa etnik ${ }^{\text {vi }}$ di Indonesia berdasarkan sebaran dan tingkat keragamannya, (2) pemetaan luasan dan cakupan lingua-franca MT dan KJ, dan (3) upayaupaya pemartabatan bahasa Indonesia. Tiga langkah mula-mula ini dapat dilakukan secara bersamaan atau dapat dilakukan secara berurutan, berdasarkan urut-waktu, bergantung pada skala pementingannya.

Tiga langkah mula-mula ini ditujukan untuk mengatasi tiga isu penting: (1) bagaimana menyelamatkan bahasa-bahasa etnik dari ancaman kepunahan, (2) bagaimana upaya-upaya yang dilakukan untuk menjaga MT dan KJ sebagai lingua franca untuk tetap menjadi "bahasa tengahan", bahasa intermediasi lintas-etnik, dan (3) bagaimana usaha pemartabatan bahasa Indonesia sebagai bahasa nasional, bahasa perekat keragaman Indonesia.

Sebagai informasi awal untuk memulai perencanaan bahasa dalam kerangka keberagaman Indonesia diperlukan semacam "peta sosiolinguistik" Indonesia sebagai pengumpan dimulainya tahap pertama perencanaan bahasa, yaitu penemuan fakta awal. Informasi awal pada bagian berikut ini merupakan amatan permukaan, hanya bersifat common sense, dan kita temukan sendiri berdasarkan amatan dan pengalaman pribadi kita.

\section{INDONESIA KINI: MULTILINGUAL YANG DIGLOSTIK ATAU TRIGLOSIK?}

Indonesia adalah negara multibahasa dan merupakan negara pemilik bahasa terbanyak kedua di dunia setelah Papua Nugini. ${ }^{\text {vii }}$ Hampir semua warga Indonesia adalah warga bilingual, bisa dan biasa menggunakan satu bahasa etnik dan MT, atau bahasa etnik dan bahasa Indonesia, atau MT dan bahasa Indonesia. Pada situasi kebahasaan seperti ini, secara sosiolinguistis, warga 
Indonesia dikelompokkan ke dalam dua kategori warga: dwibahasawan pribadi (individual bilingualism) dan dwibahasawan kelompok masyarakat (societal bilingualism). Dwibahasawan pribadi adalah sejumlah warga Indonesia yang karena mobilitas pribadinya memungkinkan mereka secara individu memperoleh bahasa kedua setelah bahasa ibunya. Sementara itu, dwibahasawan kelompok masyarakat adalah suatu situasi kebahasaan yang telah terberi atau terbentuk sebagai masyarakat yang menggunakan dua bahasa atau lebih.

Studi Sneddon (2003) serta Turner dan Wong (2010) menyimpulkan bahwa Indonesia adalah negara diglosik, dengan menunjukkan contoh-contoh penggunaan bahasa Indonesia dan KJ bagi warga Jakarta untuk fungsi dan kepentingan yang berbeda. Bahasa Indonesia sebagai varietas tinggi $^{\text {viii }}$ (selanjutnya disingkat varietas $\mathrm{T}$ ) dan $\mathrm{KJ}$ sebagai varietas rendah (selanjutnya disingkat varietas R). Dua studi ini juga menunjukkan peningkatan penggunaan KJ sebagai alat komunikasi - tidak hanya lisan-akrab-kolegial antarwarga Jakarta, tetapi juga telah menjadi repertoar bagi penyiar radio swasta di Jakarta, dan juga masuk ke naskah film, termasuk telah merajai dialog-dialog dalam sintetron kejar tayang pada sejumlah stasiun televisi swastanasional. Tak sampai di sini, KJ pun telah menjadi repertoar baru bagi perilaku berbahasa dalam komunikasi dunia maya, nge-twit dan facebook-an, bagi kawula muda dan kelas menengah Jakarta dan kota-kota besar lainnya di Indonesia. Situasi diglosik untuk Jakarta berdasarkan temuan Sneddon serta Turner dan Wong dapat digambarkan sebagai berikut (baca juga Ibrahim, 2013 dan 2015).

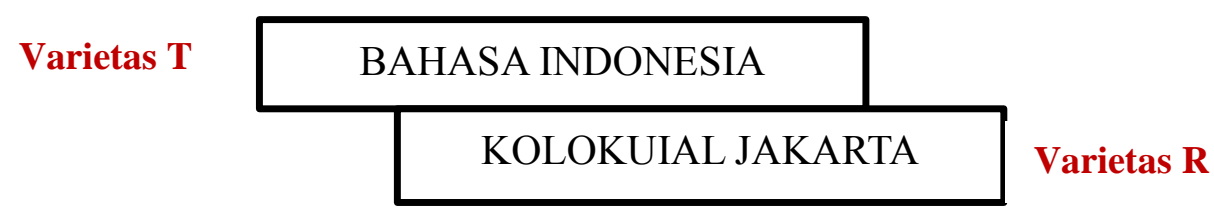

Ragaan 1. Situasi Diglosik di Jakarta (dan Sekitarnya)

Dalam dua dekade terakhir, penetrasi KJ bahkan telah merambah ke sejumlah kota penting di luar Jakarta, seperti Bandung, Surabaya, Yogyakarta, Malang, Medan, Padang, Surabaya, Denpasar, Makassar, Manado, hingga beberapa kota di Kalimantan melalui jejaring radio swasta di kota-kota ini.

Amatan dan simpulan Sneddon serta Turner dan Wong ini tentu saja hanya relevan bagi masyarakat tutur Jakarta atau hanya bisa relevan dan sahih bagi kawasan lain di Indonesia yang masyarakatnya monolingual bahasa etnik, seperti di Sunda, Jawa, beberapa kota di Sumatra, dan beberapa kota di Kalimantan. Pada kota atau kawasan monolingual seperti ini situasinya memang benar-benar diglosik: bahasa etnik untuk komunikasi akrab, santai, dalam keluarga, dan di ranah rumah; sedangkan bahasa Indonesia digunakan di dunia pendidikan, aktivitas perkantoran, dan perdagangan. Situasi diglosik seperti ini dapat digambarkan dalam ragaan berikut (baca juga Ibrahim, 2013 dan 2015).

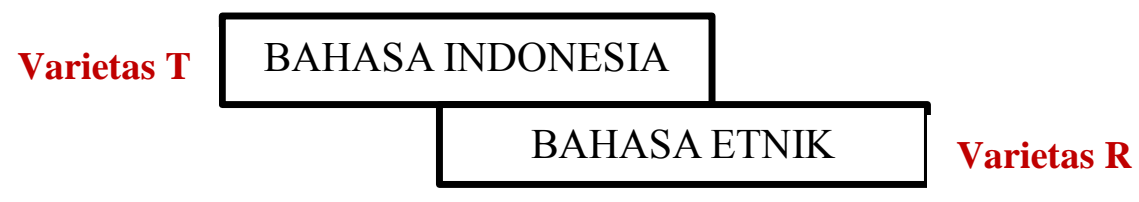

Ragaan 2. Situasi Diglosik untuk Kawasan Monolingual 
Pada kota atau kawasan multilingual, bahasa MT dipakai sebagai lingua-franca atau "jembatan sosial" bagi komunikasi lintas-etnik, seperti beberapa kawasan di Kalimantan dan sejumlah provinsi di timur Indonesia, yaitu Sulawesi, Nusa Tenggara Timur, Maluku, Maluku Utara, dan Papua. Pada kawasan multilingual tersebut, situasi kebahasaan bersifat triglosik: bahasa Indonesia digunakan di dunia pendidikan dan pemerintahan, bahasa MT sebagai sarana komunikasi lintas-etnik, sedangkan bahasa etnik digunakan untuk komunikasi di kampung, dalam keluarga, dan dalam aktivitas adat atau budaya tempatan. Ragaan mengenai situasi triglosik ini sebagai berikut (baca juga Ibrahim, 2013 dan 2015).

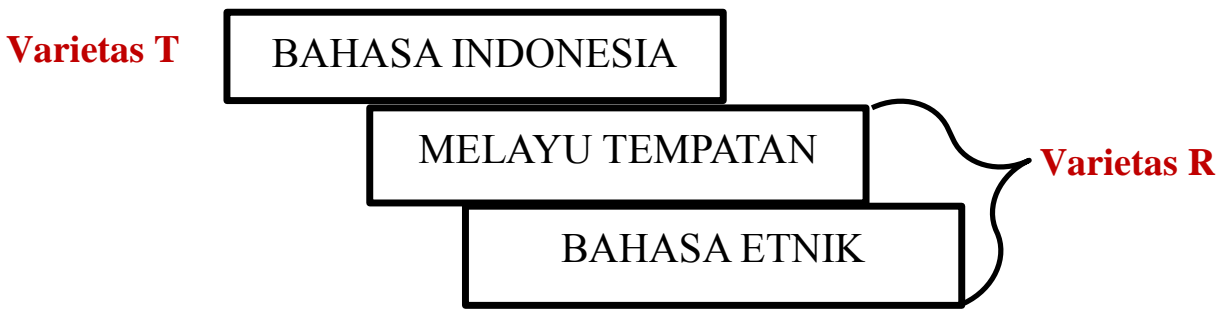

Ragaan 3. Situasi Triglosik untuk Kawasan Multilingual

\section{MENYELAMATKAN BAHASA ETNIK}

MT dalam situasi triglosik seperti yang digambarkan pada Ragaan 3 di atas semakin menjadi bahasa pertama bagi penuturnya terutama bagi etnik yang telah bergerak ke kota menjadi warga urban. Mereka tidak hanya keluar dari teritorial tradisionalnya, tetapi juga telah/sedang meninggalkan bahasa etniknya. Di satu sisi, mobilitas sosial merupakan salah satu peubah penting yang membuat semakin digunakannya bahasa MT bagi warga kota - besar, sedang, dan kecil - di sejumlah wilayah di timur Indonesia; di lain sisi (mobilitas sosial) telah menggerus jumlah penutur bahasa etnik. Peubah penting lain yang menjadikan bahasa-bahasa etnik di timur Indonesia terus tergerus adalah sikap penutur bahasa ibu dalam pilihan bahasanya. Beberapa studix $^{\text {ix }}$ membuktikan bahwa penutur bahasa etnik berusia muda di sejumlah wilayah di timur Indonesia lebih condong menggunakan bahasa MT kepada sesama teman. Sejumlah pasangan suami-istri berusia muda lebih condong membiasakan penggunaan bahasa MT kepada anakanak mereka ketimbang menggunakan bahasa etniknya. Sikap atau pilihan bahasa ini semakin memungkinkan MT menjadi bahasa pertama yang digunakan oleh anak-anak mereka. Hal itulah yang menjadi penyebab semakin tergerusnya bahasa etnik. Berubahnya sikap penutur terhadap bahasa etniknya merupakan satu dari sembilan parameter vitalitas bahasa. Sikap memilih satu bahasa lain, selain bahasa etniknya, merupakan parameter pelemah vitalitas bahasa. Bersama gerak urbanisasi, pilihan bahasa generasi muda adalah peubah penting semakin tergerusnya bahasa-bahasa etnik di timur Indonesia.

\section{POSISI INTERMEDIASI MT-KJ}

Semakin meluasnya penetrasi KJ dan semakin dipilihnya KJ menjadi bahasa pertama bagi warga kota sejumlah besar kota-kota di Indonesia menunjukkan adanya gejala sosiolinguistik baru tentang naiknya posisi dua 'ragam tengahan' (MT dan KJ) dalam kerangka triglosia Indonesia. Secara sosiologis, semakin bertambahnya jumlah penutur MT sebagai bahasa pertama warga urban dan semakin berpenetrasinya $\mathrm{KJ}$ ke ranah tutur yang selama ini menjadi 
ranah tutur bahasa Indonesia menjadi bukti lahirnya kelas menengah baru pendorong berubahnya pola relasi antarbahasa di Indonesia. Posisi intermediasi (atau varietas "bahasa tengahan") MT dan KJ tergambarkan pada Ragaan 4 berikut.

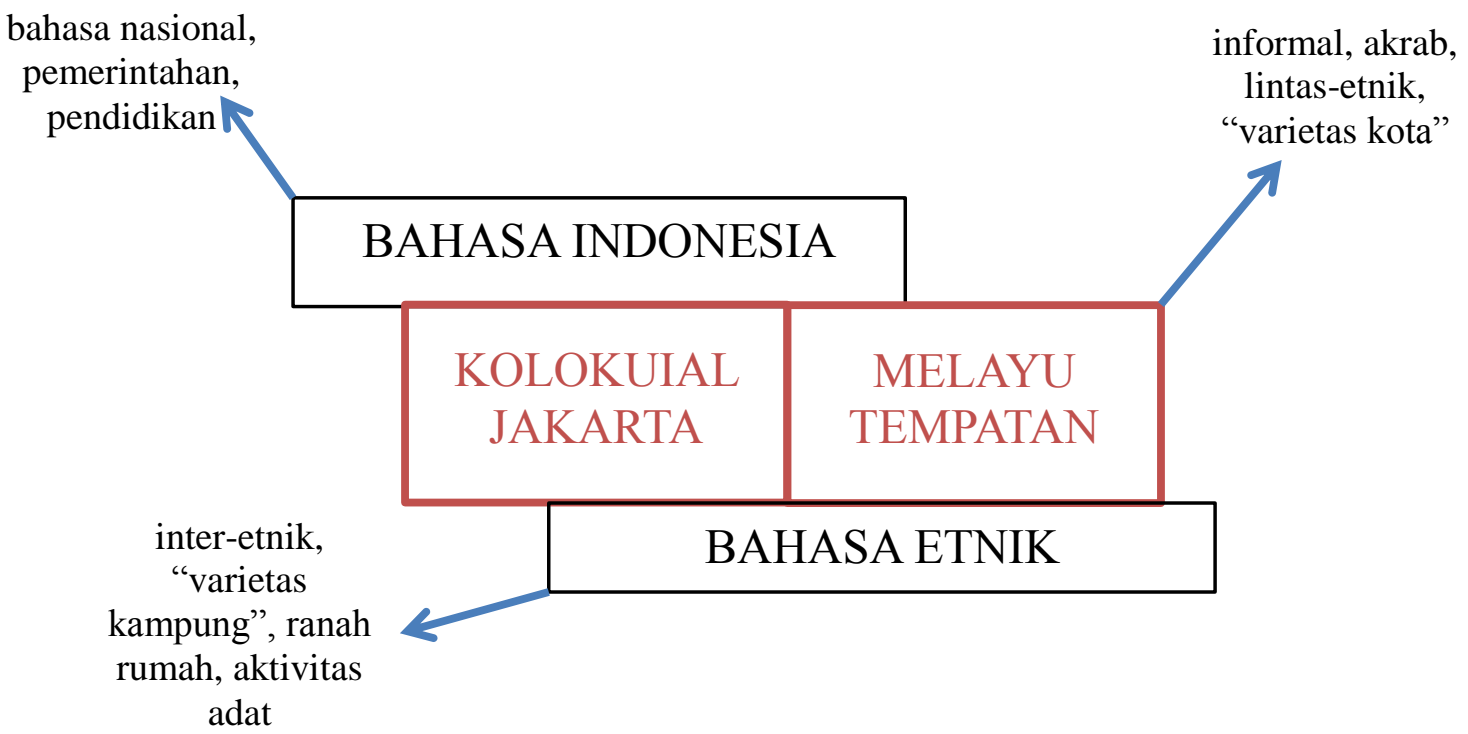

Ragaan 4. Posisi Intermediasi MT dan KJ

Ragaan 4 di atas menunjukkan bahwa MT dan KJ bersama-sama sebagai varietas tengahan dan digunakan oleh warga urban, kelas menengah, dan kawula muda. Terhadap bahasa Indonesia, MT dan KJ "menggerus ke atas" melalui meluasnya ranah pemakaiannya, bahkan melakukan penetrasi ke ruang-ruang komunikasi resmi, meskipun baru sampai pada fakta campur kode (code-switching). Terhadap bahasa-bahasa etnik, terutama di kawasan multilingual, MT menekan "ke bawah" dengan mengurangi angka absolut dan porsi penutur dalam total jumlah penduduk dalam satu kawasan teritorial bahasa etnik serta mengambil alih posisi mother tongue bahasa etnik. Gambaran mengenai "gerus ke atas" dan "tekan ke bawah" yang tengah diperankan MT dan KJ tampak pada Ragaan 5 berikut.

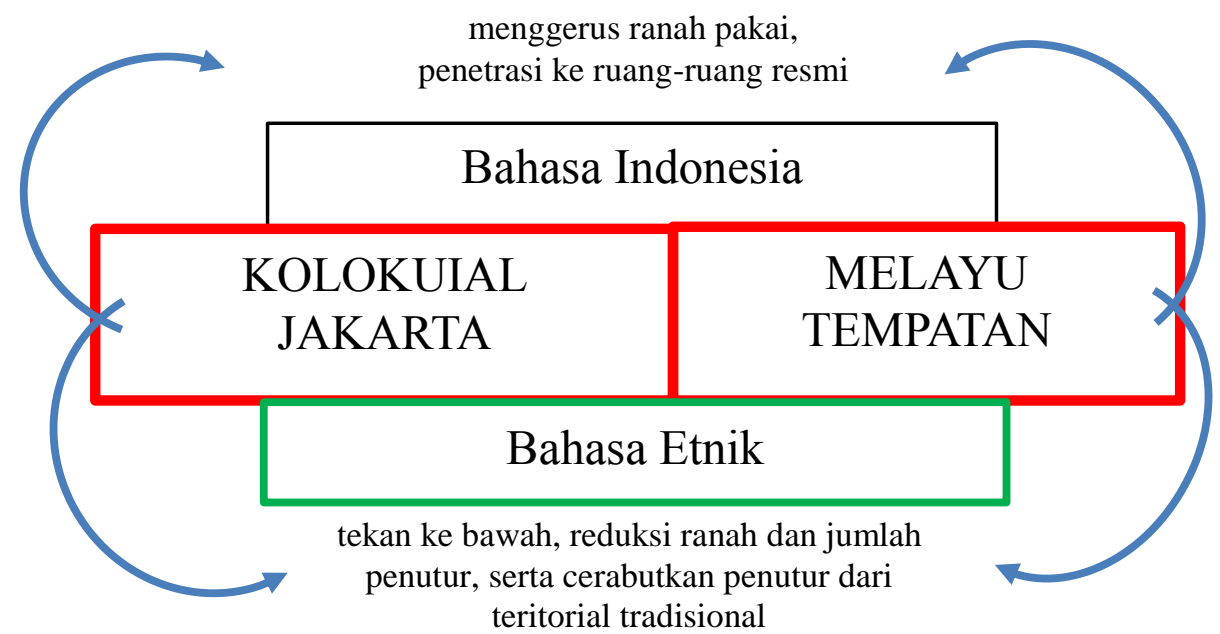

Ragaan 5. Daya Gerus dan Daya Tekan MT dan KJ 


\section{PERENCANAAN BAHASA BERBASIS DIGLOSIA-TRIGLOSIA}

Beberapa penjelasan berikut diproposalkan sebagai dasar bagi penyusunan langkah atau tahap perencanaan bahasa di Indonesia kini. Pertama, tiga profil kebahasaan yang ditunjukkan dalam Ragaan 1, 2, dan 3 di atas, yaitu situasi diglosik untuk Jakarta dan sekitarnya, situasi diglosik untuk kawasan monolingual bahasa etnik, serta situasi triglosik untuk kawasan multilingual etnik menampilkan lanskap kebahasaan di Indonesia yang 'terbelah': separuh wilayah Indonesia adalah diglosik dan separuhnya lagi adalah triglosik. Kawasan yang ditandai dengan situasi diglosik umumnya berada di wilayah barat Indonesia dan kawasan triglosik umumnya berada di wilayah timur Indonesia. Kawasan diglosik di kawasan barat Indonesia adalah kawasan tanpa lingua-franca yang mengantarai bahasa etnik dan bahasa Indonesia, sedangkan kawasan triglosik di kawasan timur Indonesia adalah kawasan yang memiliki satu bahasa lingua-franca (dalam hal ini MT) yang mengantarai bahasa etnik dan bahasa Indonesia. Bila kita menganggap Indonesia adalah negara diglosik, kita bisa menyebutnya sebagai diglosia terbelah (splitdiglossia) dan bila kita melihatnya dari sudut pandang triglosia, Indonesia adalah negara memiliki situasi kebahasaan triglosia terbelah.

Kedua, semakin meluasnya ranah pemakaian KJ ke kota-kota besar di Indonesia dan semakin berpenetrasinya KJ ke dalam ranah yang dalam politik bahasa nasional (sesuai UU Nomor 24 Tahun 2009 dan peraturan ikutannya) adalah ranah penggunaan bahasa Indonesia dan MT yang semakin menjadi bahasa pertama bagi warga urban telah menunjukkan peran kedua varietas tengahan ini akan terus memainkan peran komunikasi antarwarga urban Jakarta dan kota-kota lainnya di Indonesia. Peran-peran ini mengonfirmasi dua hal penting, yaitu (1) mobilitas dan perjumpaan lintas-etnik atau antarwarga semakin masif dan (2) tampilnya kelas menengah penghela naiknya posisi dan pamor MT dan KJ.

Ketiga, semakin tergerusnya ranah pemakaian dan semakin berkurangnya angka absolut penutur bahasa etnik di wilayah timur Indonesia menunjukkan arah pergerakan bahasa-bahasa ini ke ambang kepunahan semakin cepat. Fakta ini juga mengonfirmasi bahwa semakin ke timur Indonesia, semakin tinggi tingkat diversitas bahasa, tetapi di wilayah ini pulalah kejadian kepunahan bahasa etnik berasal.

Tiga penjelasan di atas mengonfirmasi pula bahwa Indonesia tidak hanya negara dengan 652 (Badan Bahasa, 2017) atau 722 bahasa (Lewis, 2009), tetapi juga memiliki pusparagam situasi kebahasaan. Belum lagi bila jumlah bahasa yang banyak dan pusparagam situasi kebahasaan itu dihubungkan dengan pengertian "satu bahasa merupakan pengungkap satu budaya" atau "batas-batas wilayah pakai satu bahasa berada pada garis yang sama dengan batasbatas budaya (cultural boundaries)". Kalau pikiran ini diterima sebagai kebenaran, sesungguhnya ada 652 kultur di Indonesia.

Sampai pada tingkat ini, perencanaan bahasa di Indonesia untuk memastikan tetap hidupnya bahasa-bahasa etnik, proporsionalnya peran intermediasi MT dan KJ, serta semakin bermartabatnya bahasa Indonesia perlu mendasarkan diri pada dua pijakan. Pertama, perencanaan (bahasa di Indonesia) haruslah mempertimbangkan situasi kebahasaan dan sifatpola-arah mobilitas sosial antarentik dan antarwarga sekawasan. Kedua, perencanaan bahasa haruslah disusun berdasarkan keberbedaan situasi kebahasaan di Indonesia. Perencanaan bahasa-bahasa bagi kawasan timur Indonesia lebih mempertimbangkan hubungan antara bahasa etnik dan MT di satu sisi dan hubungan antara MT dan bahasa Indonesia di lain sisi. Sementara 
itu, perencanaan bahasa untuk kawasan barat Indonesia lebih mempertimbangkan relasi antara bahasa etnik dengan KJ di satu sisi dan relasi antara KJ dan bahasa Indonesia di lain sisi.

Modusnya pun ada dua. Pertama, perencanaan korpus untuk menyelamatkan bahasabahasa etnik dari ancaman kepunahan. Kedua, untuk dua bahasa tengahan, yaitu MT dan KJ, perencanaan korpus berujung pada penetapan regulasi yang tidak saja secara proporsional, tetapi juga secara taat asas dijalankan implementasinya. Modus pertama adalah strategi penyelamatan, sedangkan modus kedua adalah penetapan regulasi untuk memastikan proporsi ranah pakai.

\section{CATATAN PERINGKAS}

Untuk menyelamatkan bahasa etnik dari ancaman kepunahan, perencanaan bahasa haruslah dilakukan dengan melibatkan perencana pembangunan, ahli perencanaan bahasa, peneliti bahasa, dan penggiat pemberdayaan masyarakat. Perencanaan ini dimulai dari pemetaan dan berakhir pada implementasi "belajar bahasa sendiri di kampung sendiri" dengan mengadopsi sekolah alam atau model interaksi dalam homeschooling. Pilihan ini cukup masuk akal karena belajar bahasa daerah (atau etnik) yang selama ini dilaksanakan di sekolah lebih banyak gagalnya daripada suksesnya.

Langkah pemetaan kembali sebaran kewilayahan dan cakupan ranah penggunaan KJ dan MT dalam konteks komunikasi antarwarga urban diperlukan untuk mengatasi ketergerusan ranah pakai bahasa Indonesia karena semakin luasnya ranah pakai KJ dan MT. Dari hasil pemetaan ini lalu ditetapkan strategi implementasi pemakaian KJ dan MT melalui regulasi yang diderivasi dari UU Nomor 24 Tahun 2009.

\section{CATATAN}

* Penulis berterima kasih kepada mitra bestari yang telah memberikan saran-saran dan masukan yang sangat berarti untuk perbaikan tulisan ini.

\section{DAFTAR PUSTAKA}

Badan Pengembangan dan Pembinaan Bahasa. (2011). Undang-Undang Republik Indonesia Nomor 24 Tahun 2009 tentang Bendera, Bahasa, dan Lambang Negara, serta Lagu Kebangsaan. Jakarta: Badan Pengembangan dan Pembinaan Bahasa.

Badan Pengembangan dan Pembinaan Bahasa. (2017). Bahasa dan Peta Bahasa di Indonesia. Jakarta: Badan Pengembangan dan Pembinaan Bahasa.

Ferguson, Charles A. (1959). Diglossia. Word 15: 325-340.

Ibrahim, G.A. (2013). Triglosia Indonesia: Merumuskan kembali relasi antarbahasa untuk keindonesiaan. Pidato pengukuhan Guru Besar dalam bidang Antropolingustik Fakultas Sastra dan Budaya Universitas Khairun, Ternate, 5 Desember 2013.

- (2015). Indonesia: Diglosia atau triglosia. Prosiding Seminar Nasional Sosiolinguistik-Dialektologi: "Kajian Sosiolinguistik dan Dialektologi dalam Konteks Kemasyarakatan dan Budaya di Indonesia”, hlm.136-155. Departemen Linguistik FIB UI bekerja sama dengan Pusat Penelitian Kemasyarakatan dan Budaya FIB UI.

Hudson, A. (2002). Outline of a theory of diglossia. International Journal of the Sociology of Language, 157: 1-48.

Lewis, P. (2009). Ethnologue: Languages of the World. Dallas: SIL International. 
Mkilifi, A.M.H. (1972). Triglossia and Swahili-English bilingualism in Tanzania. Dalam Language in Society, Vol. 1(2): 197-213.

Mukhuba, T.T. 2004. Bilingualism, language attitudes, language policy and language planning: A sociolinguitic perspective. Journal of Language and Learning, Vol. 3(2): 268-278.

Nidue, J.A. (1990). Language use in a New Guinea village: A triglossic profile of Makopin I. Language and Linguistics in Melanesia 21: 47-69.

Sallabank, Julia. (2011). Language policy for endangered languages. Dalam P.K. Austin \& J. Sallabank (eds.). The Cambridge Handbook of Endangered Languages. Cambridge: Cambridge University Press.

Schiffman, H. Tanpa tahun. Triglossia in Luxembourg: A successful triglossia. Handout for SARS 673, Multilingual Education in South/Southeast Asia. Triglossia in Luxemburg.htm.

Sneddon, J.N. (2003). Diglossia in Indonesia. Bijdragen tot de taal-Land-en Volkenkunde 159, No. 4: 519-549. www.kitlv-journals.nl.

. (2006). Colloquial Jakartan Indonesian. Canberra: Pacific Linguistics. Research School of Pacific and Asian Studies: ANU.

Turner, B. \& I. Wong. (2010). Tenor of discourse in translated diglossic Indonesian film subtitles. Dalam The Journal for Translation and Interpreting Research. Vol. 2(2).

Unesco. (2003). Language Vitality and Endangerment. Submitted to the International Expert Meeting on UNESCO Programme Safeguarding of Endangered Languages. Paris, 1012 March 2003.

\footnotetext{
'Makalah ini disampaikan pada Kongres Internasional Masyarakat Linguistik Indonesia (KIMLI) 2018, di Universitas Negeri Papua, Manokwari, 13-16 Agustus 2018. Versi pertama makalah ini dibentangkan sebagai makalah utama pada Diseminasi dan Seminar Nasional Bahasa dalam Dimensi Kemasyarakatan dan Kebudayaan yang diselenggarakan oleh Pusat Penelitian Kemasyarakatan dan Kebudayaan, Lembaga Ilmu Pengetahuan Indonesia, 10-11 Desember 2013. Meskipun demikian, makalah ini belum pernah diterbitkan.

ii Situasi kebahasaan satu bahasa dengan varietas yang agak berbeda digunakan oleh satu komunitas yang sama dalam fungsi yang berbeda atau ada dua bahasa yang berbeda digunakan oleh komunitas tutur yang sama untuk fungsi dan keperluan yang berbeda (lihat misalnya Ferguson, 1959; Hudson, 2002).

${ }^{\text {iii }}$ Situasi kebahasaan tiga bahasa digunakan oleh satu komunitas yang sama untuk fungsi dan keperluan yang berbeda, seperti yang terjadi di Tanzania: bahasa Inggris untuk pemerintahan dan diplomasi internasional, bahasa Swahili sebagai bahasa nasional, lingua-franca, bahasa lintas-etnik, dan bahasabahasa etnik lain dalam komunikasi intra-etnik (Mkilifi, 1972). Di Makopin Papua Nugini digunakan tiga bahasa: bahasa Inggris untuk perdagangan dan diplomasi internasional, bahasa Tok Pisin untuk pendidikan dan komunikasi pemerintahan lokal, dan bahasa Aparesh Pegunungan untuk komunikasi intra-entik digunakan di rumah dan untuk aktivitas budaya tempatan (Nidue, 1990). Juga seperti penggunaan tiga bahasa di Luxemburg: bahasa Jerman digunakan di pendidikan dasar, agama, dan jurnalistik; bahasa Perancis digunakan di pendidikan menengah, pemerintahan, dan tanda-nama-marka jalan; sedangkan Lëtsebuergecsh adalah bahasa yang digunakan di rumah, di jalan, dan tempat kerja (Schiffman, tanpa tahun).

${ }^{\text {iv }}$ Istilah MT di sini digunakan untuk merujuk kepada varietas Melayu yang tersebar di beberapa wilayah di Indonesia yang telah berinteraksi (saling pinjam kosakata dan struktur) dengan bahasa-(bahasa) etnik setempat. MT tersebut adalah Melayu Betawi (yang kini bermetamorfosis menjadi apa yang disebut oleh Sneddon (2006) sebagai KJ), Melayu Makassar, Melayu Manado, Melayu Riau, Melayu Banjar, Melayu Larantuka, Melayu Ambon, Melayu Ternate, Melayu Papua, dan Melayu lain di sejumlah wilayah ibu kota provinsi di Indonesia.
} 


\footnotetext{
${ }^{\vee}$ KJ adalah sebutan yang diberikan oleh Sneddon (2006) untuk merujuk pada varietas bahasa warga Jakarta kini. Sebutan ini merujuk kepada Melayu Betawi yang telah mengalami 'metamorfosis' kata dan stuktur kalimat, yang membuatnya sudah agak sedikit berbeda dengan Melayu Betawi pada kira-kira tahun 1970-1990-an atau sebelumnya.

${ }^{\mathrm{vi}}$ Unesco (2003) mencatat ada sembilan parameter penanda vitalitas atau daya hidup bahasa (language vitality): (1) jumlah absolut penutur, (2) transmisi bahasa antargenerasi, (3) sikap anggota penutur terhadap bahasanya, (4) pergeseran dalam ranah penggunaan bahasa, (5) sikap dan kebijakan pemerintah dan lembaga terhadap status keresmiaan bahasa, (6) kualitas dan jenis dokumentasi, (7) respons terhadap ranah baru dan media, (8) ketersediaan bahan ajar bahasa dan keberaksaraan, dan (9) proposisi penutur dalam keseluruhan penduduk.

vii Badan Pengembangan dan Pembinaan Bahasa Kemendikbud menyebut ada 652 bahasa di Indonesia. Menurut catatan Ethnologue: Languages of the world (Lewis, 2009), ada 830 bahasa di Papua Nugini dan ada 722 bahasa di Indonesia.

viii Istilah varietas tinggi dan varietas rendah ini merupakan adaptasi dari istilah high register $(\mathrm{H})$ dan low register (L) yang diperkenalkan Ferguson (1959) sehubungan dengan dua ragam bahasa yang agak berbeda untuk satu bahasa yang sama dan digunakan untuk ranah dan fungsi yang berbeda, seperti fungsi bahasa Spanyol dan Guarani di Paraguay, Yunani Klasik dan Yunani Kolokuial di Yunani, Jerman Tinggi dan Jerman Swiss di Swiss, Arab Klasik dan Arab Kolokuial di negara-negara Timur Tengah, Perancis dan Kreyol di Haiti, serta bahasa Inggris dan Tagalog/Filipino di Filipina.

${ }^{\text {ix }}$ Survei tentang sebaran dan pola-pola penggunaan bahasa masyarakat multilingual di Maluku Utara yang dilakukan oleh Fakultas Sastra dan Budaya Universitas Khairun menemukan fakta bahwa pasangan usia muda suami-istri penutur bahasa etnik di Maluku Utara lebih sering menggunakan bahasa Melayu Ternate (lingua-franca) kepada anak-anak mereka ketimbang menggunakan bahasa etnik.
} 